\title{
Hubungan Persepsi Petugas Kesehatan dengan Kepatuhan Terhadap Upaya Pencegahan Penyebaran Wabah Covid-19 di Area GBPT RSUD Dr. Soetomo
}

\author{
Nining Dwi Suti Ismawati ${ }^{1 *}$, Stefanus Supriyanto ${ }^{2}$, Setya Haksama ${ }^{3}$ \\ ${ }^{1}$ Mahasiswa Doktoral Ilmu Kesehatan Masyarakat, Fakultas Kesehatan Masyarakat, Universitas \\ Airlangga \\ ${ }^{2,3}$ Departemen Administrasi dan Kebijakan Kesehatan, Fakultas Kesehatan Masyarakat Universitas \\ Airlangga
}

\begin{abstract}
ABSTRAK
COVID-19 adalah penyakit menular yang disebabkan oleh jenis coronavirus yang baru ditemukan. Ini merupakan virus baru dan penyakit sebelumnya tidak dikenal sebelum terjadi wabah di Wuhan, Tiongkok pada bulan Desember 2019. Coronavirus adalah suatu kelompok virus yang dapat menyebabkan penyakit pada hewan atau manusia. Kecepatan epidemi tergantung pada dua hal, yakni berapa banyak orang yang terinfeksi dari satu kasus dan berapa lama infeksi antar orang menyebar. Hingga saat ini tercatat 209 negara yang terpapar COVID-19 Pemerintahan Indonesia sudah berupaya dalam memutus sebaran virus COVID-19 dengan beberapa langkah yaitu menghimbau masyarakat tidak mendatangi atau mengadakan acara yang dapat mengumpulkan banyak orang. Berdasarkan latar belakang tersebut, penelitian ini bertujuan untuk mengetahui ada atau tidak hubungan persepsi petugas kesehatan dengan kepatuhan terhadap himbauan pemakaian masker, social distancing, dan cuci tangan di area GBPT RSUD $d r$. Soetomo dalam upaya pencegahan penyebaran wabah COVID-19. Responden penelitian ini berjumlah 50 oranag yang berprofesi sebagai dokter, perawat, tenaga administrasi, dan transporter dihitung menggunakan teknik menggunakan purposive sampling. Pengambilan data dilakukan dengan menggunakan instrumen berupa kuisioner dan lembar checklist observasi, menggunakan uji statistik Chi-Square dengan memanfaatkan program SPSS. Hasil penelitian ini menunjukkan adanya hubungan yang bermakna antara persepsi petugas kesehatan dengan kepatuhan. Kesimpulan penelitian adalah perlunya himbauan pemakaian masker di area GBPT RSUD Dr. Soetomo dalam upaya pencegahan penyebaran wabah COVID-19 pada tenaga kesehatan terutama yang berprofesi sebagai perawat.
\end{abstract}

Kata kunci: COVID-19; persepsi; kepatuhan; penggunaan masker; social distancing; cuci tangan

\begin{abstract}
Introduction: COVID-19 is an infectious disease caused by a newly discovered type of coronavirus. This is a new virus and a previously unknown disease before the outbreak in Wuhan, China in December 2019. A coronavirus is a group of viruses that can cause disease in animals or humans. The speed of the epidemic depends on two things, namely how many people are infected in a single case and how long it takes between people to spread the infection. Until now, 209 countries have been affected by COVID-19. The Indonesian government has made efforts to cut the spread of the COVID-19 virus with several steps, namely urging the public not to come or hold events that can gather many people. Aim of study: Based on this background, this study aims to determine whether or not there is a relationship between perceptions of health workers and adherence to the appeal for wearing masks, social distancing, and washing hands in the GBPT area of dr. Soetomo to prevent the spread of the COVID-19 outbreak. Method: The number of respondents in this study were 50 people who work as doctors, nurses, administrative staff, and transporters and were calculated using a purposive sampling technique. Data were collected using instruments in the form of questionnaires and observation checklist sheets, using the Chi-Square statistical test using the SPSS program. Results and Discussion: The results of this study indicate that there is a significant relationship between perceptions of health workers and adherence. Conclusion: It can be concluded that there is a need to wear masks in the GBPT area of Dr. Soetomo to prevent the spread of the COVID-19 outbreak to health workers, especially those who work as nurses.
\end{abstract}

Keywords: COVID-19; perception; compliance; use of masks; social distancing; wash hands

*Korespondensi penulis:

Nama : Nining Dwi Suti Ismawati

Instansi : Fakultas Kesehatan Masyarakat, Universitas Airlangga

Alamat : Jl. Dr. Ir. H. Soekarno, Mulyorejo, Kec. Mulyorejo, Kota SBY, Jawa Timur. 085850645335

Email : nining.dwi.suti-2017@fkm.unair.ac.id 


\section{Pendahuluan}

Saat ini Indonesia tengah berada dalam pandemi oleh wabah virus yang dinamakan COVID-19. COVID-19 adalah penyakit menular yang disebabkan oleh jenis coronavirus yang baru ditemukan. Ini merupakan virus baru dan penyakit sebelumnya tidak dikenal sebelum terjadi wabah di Wuhan, Tiongkok pada bulan Desember 2019. Coronavirus adalah suatu kelompok virus yang dapat menyebabkan penyakit pada hewan atau manusia. Beberapa jenis coronavirus diketahui menyebabkan infeksi saluran pernafasan manusia mulai dari batuk, pilek hingga yang lebih serius seperti Middle East Respiratory Syndrome dan Severe Acute Respiratory Syndrome. ${ }^{1}$ COVID-19 dapat menular melalui manusia ke manusia yang terjangkit virus ini. Tidak hanya orang yang memiliki gejala seperti flu, namun adapula orang yang sehat dan tidak memiliki gejala apapun juga dapat terinfeksi virus COVID19. Sekitar $80 \%$ orang yang terinfeksi berhasil sembuh tanpa perlu perawatan khusus, tetapi akan sangat berbahaya jika virus tersebut menginfeksi orang lanjut usia atau yang memiliki riwayat penyakit kronis seperti tekanan darah tinggi, gangguan jantung, diabetes, penyakit paru-paru dan kanker.

Kecepatan epidemi tergantung pada dua hal, yakni berapa banyak orang yang terinfeksi dari satu kasus dan berapa lama infeksi antar orang menyebar. Hingga saat ini tercatat 209 negara yang terpapar COVID-19 dibeberapa negara besar, yaitu Tiongkok, Italia, Korea Selatan, Spanyol Amerika Serikat, dan juga Indonesia. Secara global diketahui 1.136.851 kasus yang terkonfirmasi dan kematian yang mencapai 62.955 jiwa. Di Indonesia pada 21 Maret 2020 tercatat yang positif sebanyak 369 kasus, sembuh 17 kasus dan meninggal 32 kasus. Sedangkan per tanggal 21 April 2020 kasus yang positif mencapai 7.135 kasus, pasien yang sembuh dari COVID-19 sebanyak 842 kasus, dan yang meninggal sebanyak 616 orang. Bertambahnya kasus COVID-19 juga dikarenakan adanya kebijakan pemerintah melakukan Rapid Test atau tes massal yang sudah diterapkan dibeberapa wilayah Indonesia khusunya DKI Jakarta. Pada wilayah provinsi Jawa Timur juga terdapat kasus positif sebanyak 603 kasus, sembuh sebanyak 101 kasus, dan meninggal sebanyak 58 kasus data tersebut tercatat per tanggal 21 April 2020. Sedangkan di Surabaya sendiri per tanggal 21 April 2020 tercatat ada kasus positif atau terkonfirmasi sebanyak 301 kasus, sembuh sebanyak 46 kasus, dan meninggal sebanyak 33 kasus. $^{2}$

Pemerintahan Indonesia sudah berupaya dalam memutus sebaran virus COVID-19 dengan beberapa langkah yaitu menghimbau masyarakat tidak mendatangi atau mengadakan acara yang dapat mengumpulkan banyak orang. Menghimbau kepada seluruh perusahaan atau tempat kerja untuk menerapkan sistem work from home, menghimbau masyarakat agar tetap dirumah tidak keluar jika tidak ada kepentingan mendesak, dan juga menghimbau untuk menerapkan social distancing atau physical distancing. Saat ini sedang berlangsung kebijakan pemerintah dengan menerapkan PSBB atau Pembatasan Sosial Berskala Besar yang didasarkan kebijakan Peraturan Gubernur Jawa Timur Nomor 18 tahun 2020 tentang Pedoman Pembatasan Sosial Berskala Besar dalam Penanganan Corona Virus Disease 2019 (COVID-19) di Provinsi Jawa Timur. ${ }^{3}$

Sebelum menyentuh bagian wajah terutama mata, hidung, dan mulut, serta pada saat sebelum makan dan sesudah menyentuh barang. Masyarakat dihimbau untuk selalu menjaga kebersihan diri ataupun lingkungan sekitarnya. Mulai dari megkonsumsi makanan bergizi seimbang, melakukan olahraga teratur atau beraktivitas fisik, berjemur dibawah sinar matahari, dan mengkonsumsi supelmen vitamin yang dapat menstabilkan sistem imunitas tubuh. Sedangkan juga diterapkanya social distancing atau physical distancing menjaga jarak dengan orang lain sedikitnya 1 meter saat berjalan, berbicara, duduk, ataupun berdiri. Dapat diterapkan dengan mengurangi menggunakan transportasi umum dan 
menggunakan masker saat hendak keluar rumah. Tenaga kesehatan memiliki risiko yang lebih tinggi dibandingkan masyarakat umum. Hal ini dikarenakan tenaga kesehatan berhadapan langsung dalam penanganan pasien terinfeksi virus COVID-19 ataupun tidak.

Maka penelitian ini dilakukan untuk mengetahui bagaimana hubungan perepsi dengan kepatuhan petugas kesehatan terhadap himbauan pemakaian masker, penerapan social distancing atau physical distancing, dan mencuci tangan di wilayah kerja instalasi GBPT RSUD dr. Soetomo Surabaya dalam pencegahan penyebaran wabah COVID-19 di lingkungan kerja. Adapun manfaat dari penelitian ini adalah untuk mengetahui kebiasaan pegawai dalam kewaspadaan universal perkuasen penyakit infeksi menular sebagai bentuk melaksanakan SOP atau tidak meskipun telah tidak ada wabah.

\section{Metode}

Jenis penelitian ini adalah penelitian observationalanalitik dengan desain penelitian cross-sectional. Penelitian ini dilakukan di wilayah kerja Gedung Bedah Pusat Terpadu (GBPT) RSUD Dr. Soetomo yang berlokasi di Jalan Prof. Dr. Moestopo no. 6-8 Surabaya pada bulan April 2020 hingga Mei 2020. Tujuan dari penelitian ini adalah untuk mengetahui ada atau tidak hubungan persepsi petugas kesehatan dengan kepatuhan terhadap himbauan pemakaian masker, social distancing, dan cuci tangan di area GBPT RSUD dr. Soetomo dalam upaya pencegahan penyebaran wabah COVID-19.

Pengambilan data dilakukan dengan menggunakan instrumen berupa kuisioner dan lembar checklist observasi. Variabel yang diteliti pada penelitian ini terdiri dari persepsi dan kepatuhan petugas kesehatan terhadap penggunaan masker, penerapan cuci tangan, dan penerapan social distancing. Penelitian ini telah mendapat sertifikat etik oleh Komisi Etik RSUD Dr. Soetomo. Pengolahan data penelitian ini menggunakan uji statistik Chi-Square yang digunakan untuk mengetahui hubungan antara pertanyaan kuisioner dengan ceklist obeservasi.
Sampel penelitian ini berjumlah 50 orang yang berprofesi sebagai dokter, perawat, transporter, dan tenaga administrasi dihitung menggunakan purposive sampling. Yang mana respondennya merupakan seluruh pegawai RSUD Dr. Soetomo yang memasuki area GBPT. Instrument yang digunakan adalah berupa lembar kuisioner yang akan diisi oleh responden dan lembar ceklist observasi pada setiap responden.

\section{Hasil dan Pembahasan}

Berdasarkan jenis kelamin responden, Karakteristik jenis kelamin responden dibagi menjadi dua kelompok, yaitu laki-laki dan perempuan. diketahui bahwa responden pada penelitian ini berjumlah 50 orang, yang terdiri atas 31 orang $(62 \%)$ berjenis kelamin laki-laki dan 19 orang (38\%) berjenis kelamin perempuan. Berdasarkan pelayanan utama sebagai pusat pembeahan petugas yang berada di wilayah kerja GBPT atau mengunjungi GBPT memiliki profesi yang terdiri dari perawat, PPDS, dokter, transporter dan administrasi. diketahui bahwa responden pada penelitian ini berjumlah 50 orang, yang terdiri atas 7 orang (14\%) berprofesi sebagai administrasi, 15 orang (32\%) sebagai perawat, 22 orang (43\%) berprofesi sebagai dokter, dan 5 orang (10\%) berprofesi sebagai transporter. Profesi responden yang banyak mengunjungi GBPT sesuai dengan proses pelayanan yang terdapat pada fasiltas GBPT yaitu pusat pelayanan pembedahan dan ruang intensif dilakukan oleh sebagaian besar dokter dan perawat RSUD Dr. Soetomo Surabaya.

\section{Hubungan antara Kuisioner Tentang Penggunaan Masker dan Ceklist Observasi dalam Tindakan Penggunaan Masker}

Peraturan/Kebijakan tentang prosedur penggunaan APD terutama masker bedah di rumah sakit sangatlah penting, karena dengan adanya kebijakan ini, perawat akan dapat lebih tahu tentang pentingnya penggunaan masker, sehingga dapat mencegah terjadinya terpapar virus pada saat melakukan tindakan prosedur 
medis pada pasien. Didukung oleh lingkungan sekitar yang saat ini di Indonesia sedang menghadapi pandemi virus COVID-19 dan RSUD Dr. Soetomo menjadi rumah sakit rujukan khusus pasien COVID-19 di Jawa Timur. Alat pelindung diri (APD) yang harus digunakan pada tenaga kesahatan yang tidak secara langsung bersentuhan dengan pasien, petugas yang sedang bersama atau mengantar pasien adalah berbeda. Dari hasil observasi didapatkan data sebagai berikut:

Tabel 1. Hubungan Persepsi dan Tingkat Kepatuhan Penggunaan Masker Pada Petugas Kesehatan di Instalasi GBPT RSUD Dr. Soetomo Surabaya

\begin{tabular}{lccccc}
\hline \multirow{2}{*}{ Profesi } & \multicolumn{2}{c}{ Persepsi } & \multicolumn{2}{c}{ Kepatuhan } & $\boldsymbol{p}$ - \\
& $\mathbf{P}$ & TP & P & TP & value \\
\hline Admin & 2 & 5 & 5 & 2 & 1,000 \\
Perawat & 4 & 12 & 7 & 9 & 0,019 \\
Dokter & 2 & 20 & 2 & 20 & 0,177 \\
Transporter & 1 & 4 & 2 & 3 & 0,444 \\
\hline
\end{tabular}

Dari hasil uji statistik dengan menggunakan chi-square pada tabel 1 didapatkan hasil bahwa ada hubungan yang bermakna antara kuisioner penggunaan masker dengan ceklist obersvasi terdapat pada profesi perawat sebesar $(0,019)<0,05$. Sedangkan pada profesi dokter sebesar $(0,177)>0,05$. Pada profesi tenaga transpoter mengasilkan pvalue sebesar $(0,444)>0,05$, dan pada profesi tenaga administrasi menghasilkan pvalue sebesar $(1,000)>0,05$. Pada tenaga kessehatan yang berprofesi sebagai dokter, tenaga administrasi, dan transporter dapat disimpulkan bahwa tidak adanya hubungan yang bermakna antara kuisoner dengan ceklist observasi tentang penggunaan masker.

Berdasarkan dari hasil penelitian yang dilakukan terhadap 50 pekerja yang bertugas di Instalasi GBPT RSUD Dr. Soetomo pada Mei 2020, diketahui bahwa pekerja memilki perilaku yang hampir seimbang antara kepatuhan penggunaan masker dengan persepsi mengenai pentingnya penggunaan masker. Hasil dari penelitian ini adalah adanya hubungan yang signifikan antara persepsi petugas kesehatan dengan kepatuhan penggunaan masker dengan memperoleh hasil pvalue sebesar $(0,000)<0,05$. Adanya hubungan yang bermakna terdapat pada tenaga kesehatan yang berprofesi sebagai perawat, sedangkan untuk profesi yang lain menyatakan tidak adanya hubungan yang bermakna antara persepsi pentingnya penggunaan masker dengan kepatuhan penggunaan masker. Didukung dengan penelitian Zahara, 2017 yang menyatakan bahwa sebagaian besar petugas kesehatan yang ada dirumah sakit mengetahui manfaat penggunaan masker dan dengan adanya himbauan mengenai hal tersebut, akan tetapi karena tida adanya sanksi masih ada beberapa petugas yang mengabaikannya dengan menggunaan masker secara tidak standar. ${ }^{4}$

Kebijakan merupakan faktor pendorong yang akan memperkuat suatu tindaan yang terjadi pada seseorang. Adanya himbauan dapat menjadi salah satu faktor untuk seseorang dapat mematuhi dalam penggunaan masker bedah di wilayah rumah sakit, terlebih jika tenaga kesehatan medis dan non medis berhubungan langsung untuk melakukan perawatan untuk pasien. ${ }^{5}$ Pada tenaga administrasi rumah sakit yang masih kurang dalam kepatuhan penggunaan masker, terlebih jika sering berhadapan dengan pasien, keluarga pasien, ataupun sangat sering berinteraksi dengan orang lain, sangat disarankan menambah APD berupa face shield yang diharapkan akan bisa meindungi terapar atau terkontaminasi pada saat berhadapan dengan orang lain.

Didukung oleh data dari Diryan RSUD Dr. Soetomo Surabaya yang memaparkan bahwa persentase paling banyak terpapar kepositifan oleh kasus COVID-19 banyak terdapat pada tenaga kerja yang berprofesi sebagai tenaga administrasi sebanyak 29.8\%. Salah satu penyebab dikarenakan masih kurang patuhnya tenaga kesehatan dan tenaga administrasi dalam menjalankan atau melaksanakan himbauan untuk memakai masker dengan baik dan benar. Penggunaan masker dengan baik dan benar 
adalah langkah pencegahan dan pengendalian yang komprehensif dapat mencegah penyebaran virus termasuk COVID-19.

Fasilitas yang telah berikan oleh rumah sait adalah penyedian alat pelindung diri atau APD salah satunya adalah masker yang dapat digunakan ketika bekerja. Serta memasang rambu-rambu mengenai kewajiban penggunaan APD ditempat kerja. Sedangkan pekerja juga wajib memakai masker saat bekerja. Rumah sakit juga telah mengumumkan secara tertulis melalui surat dengan nomor 440/5900/301/1/2020 pada 08 Apri 2020 yang berisi tentang "Pemberitahuan Kewajiban Pemakaian Masker di Lingkungan RSUD Dr. Soetomo".

Ketersediaan APD merupakan salah satu faktor pendukung (enabling faktor) yang terdapat dalam teori perilaku kesehatan Green. Kepatuhan merupakan tindakan yang dilakukan seseorang atas anjuran atau informasi yang diperoleh melaui berbagai sumber dalam hal ini perusahann penyelenggara jasa kebersihan. Faktor yang menjadi penyebab tidak adanya hubungan antara jenis kelamin dengan kepatuhan salah satunya adalah jumlah pekerja yang bekerja memiliki perbedaan jumlah antara laki-laki dan perempuan yang banyak. Hal ini karena apapun jenis kelaminnya tidak mempengaruhi menggunakan atau tidak menggunakan APD. Jenis kelamin laki-laki atau perempuan mempunyai kesempatan yang sama untuk menggunakan atau tidak menggunakan APD. ${ }^{6}$

\section{Hubungan antara Kuisioner Tentang Cuci Tangan dan Ceklist Observasi dalam Tindakan Cuci Tangan}

Penerapan cuci tangan harus dilakukan dengan 6 langkah yang benar sesuai dengan ketentuan yang telah ditetapkan oleh WHO (World Health Organization). Cuci tangan yang baik dilakukan dengan menggunakan air mengalir dan sabun ataupun dengan Handscrub atau Handsanitizer. Data kepatuhan penerapan cuci tangan didapatkan dari observasi peneliti selama petugas kesehatan bertugas. Dari hasil observasi didapatkan data sebagai berikut:

Tabel 2. Tingkat Kepatuhan Penerapan Cuci

Tangan Pada Petugas Kesehatan di Instalasi GBPT RSUD Dr. Soetomo Surabaya

\begin{tabular}{|c|c|c|c|c|c|}
\hline \multirow{2}{*}{ Profesi } & \multicolumn{2}{|c|}{ Persepsi } & \multicolumn{2}{|c|}{ Kepatuhan } & \multirow{2}{*}{$\begin{array}{c}p- \\
\text { value }\end{array}$} \\
\hline & $\mathbf{P}$ & TP & $\mathbf{P}$ & TP & \\
\hline Admin & 0 & 7 & 6 & 1 & 1,000 \\
\hline Perawat & 4 & 12 & 9 & 7 & 1,000 \\
\hline Dokter & 5 & 17 & 8 & 14 & 1,000 \\
\hline Transporter & 1 & 4 & 4 & 1 & 1,000 \\
\hline
\end{tabular}

Dari hasil uji statistik dengan menggunakan chi-square pada tabel 2 didapatkan hasil bahwa tidak adanya hubungan yang bermakna antara kuisioner tentang penerapan cuci tangan dengan ceklist obersvasi terdapat pada profesi perawat, dokter, tenaga administrasi maupun tenaga transporter. Pada 4 profesi tersebut masing-masing mendapat kan hasil pvalue sebesar $(1,000)>0,05$. Penerapan cuci tangan merupakan salah satu prioritas dalam pencegahan infeksi nosokomial. Mikroorganisme yang terdapat pada tangan dapat berkurang sebanyak $36 \%$ apabila dicuci menggunakan air mengalir dan sabun. Dengan berkurangnya mikroorganisme pada tangan, maka transmisi silang yang terjadi akan lebih sedikit.

Mencuci tangan merupakan kegiatan yang penting bagi lingkungan tempat klien dirawat, termasuk rumah sakit. ${ }^{7}$ Mencuci tangan merupakan rutinitas yang murah dan penting dalam pengontrolan infeksi, dan merupakan metode terbaik untuk mencegah transmisi mikroorganisme. Tindakan mencuci tangan telah terbukti secara signifikan menurunkan infeksi. Mencuci tangan merupakan tindakan yang paling efektif untuk mengontrol infeksi nosokomial (infeksi yang berasal dari rumah sakit) dan didefinisikan sebagai menggosok seluruh permukaan kedua tangan menggunakan sabun dengan kuat dan bersamaan. ${ }^{8}$

Perilaku cuci tangan dilakukan pada 5 momen dengan 6 langkah mencuci tangan sesuai dengan pedoman WHO, akan tetapi sejak 
pandemi ini seluruh masysrakat dihimbau untuk rajin cuci tangan. Mencuci tangan itu sendiri dapat dilakukan menggunakan alcohol rub atau handscrub maupun air mengalir dan sabun. Pada saat pelaksanaannya, mencuci tangan idealnya dilakukan selama 20-30 detik jika menggunakan handscrub, 40-60 detik jika menggunakan sabun dan air mengalir untuk memaksimalkan potensi agen antiseptik untuk menghilangkan bakteri dan kotoran pada tangan.

$$
\text { Berdasarkan hasil uji chi-square }
$$
kepatuhan dan persepsi responden diperoleh pvalue sebesar 0,777 pada seluruh responden dan oleh karena nilai pvalue $(0,777>0,05)$, sehingga berarti tidak adanya hubungan bermakna antara persepsi pentingnya cuci tangan dengan kepatuhan penerpan cuci tangan pada tenaga kesehatan yang berada di wilayah kerja Instalasi GBPT RSUD Dr. Soetomo Surabaya. Pada tenaga administrasi rumah sakit yang masih kurang dalam kepatuhan penerapan cuci tangan, terlebih jika sering berhadapan dengan pasien, keluarga pasien, ataupun sangat sering berinteraksi dengan orang lain, sangat disarankan menambah intesnsitas mencuci tangan jika hendak memegang area wajah, makan, ataupun telah memegang suatu benda yang diharapkan akan mengurangi risiko terpapar virus COVID-19.

Persepsi tenaga kesehatan mengenai kewajiban mencuci tangan dapat dibentuk melalui proses penerimaan rangsangan dari panca indera yang baik sehingga dapat menghasilkan tafsiran rangsangan yang baik yaitu berbentuk persepsi. Penelitian serupa juga menyatakan bahwa terdapat korelasi yang positif antara persepsi dengan kepatuhan penerapan cuci tangan petugas kesehatan. Fasilitas rumah sakit yang telah tersedia berupa handscrub yang tersedia di setiap lantai seperti di depan lift, pintu masuk gedung, kantin, dan sebelah mesin fingerprint. Dan juga wastafel yang tersedia di setiap toilet, seharusnya dengan adanya fasilitas yang telah tersedia meningkatnya kepatuhan terhadap penerapan cuci tangan sebagai upaya untuk membantu memutus tali penyebaran virus COVID-19. ${ }^{9}$

\section{Hubungan antara Kuisioner Tentang Social Distancing dan Ceklist Observasi dalam Tindakan Social Distancing}

Penerapan social distancing atau physical distancing sesuai dengan ketentuan yang telah ditetapkan oleh WHO (World Health Organization) dengan menjaga jarak aman minimal 1-1,5 meter dengan orang disekitar pada saat berdiri, duduk, maupun berbicara dalam upaya untuk memutus rantai penyebaran virus COVID-19. Data kepatuhan penerapan social distancing atau physical distancing dari observasi peneliti selama petugas kesehatas bertugas. Dari hasil observasi didapatkan data sebagai berikut:

Tabel 3. Tingkat Kepatuhan Penerapan Social Distancing atau Physical Distancing pada Petugas Kesehatan di Instalasi GBPT RSUD Dr. Soetomo Surabaya

\begin{tabular}{cccccc}
\hline \multirow{2}{*}{ Profesi } & \multicolumn{6}{c}{ Persepsi } & \multicolumn{3}{c}{ Kepatuhan } & \multirow{2}{*}{ pvalue } \\
\cline { 2 - 5 } & $\mathbf{P}$ & TP & P & TP & \\
\hline Admin & 0 & 7 & 6 & 1 & 1,000 \\
Perawat & 4 & 12 & 9 & 7 & 1,000 \\
Dokter & 5 & 17 & 8 & 14 & 1,000 \\
Transporter & 1 & 4 & 4 & 1 & 1,000 \\
\hline
\end{tabular}

Pada tabel 3 diketahui bahwa pada tenaga yang berprofesi sebagai administrasi yang mempunyai persepsi yang baik terhadap penerapan social distancing sebanyak 3 orang dan tiyang memiliki kategori kurang baik sebanayak 4 orang. Akan tetapi pada kepatuhan petugas administrasi dalam penerapan social distancing tergolong rendah karena lebih banyak yang tidak patuh dalam penggunaan masker sebanyak 5 orang dibanding dengan yang patuh dalam penerapan cuci tangan sebanyak 2 orang. Pada yang berprofesi sebagai perawat yang memiliki kategori baik dalam persepsi pentingnya penerapan social distancing sebanyak 13 orang, sedangkan yang memiliki kategori kurang baik sebanyak 3. Pada variabel kepatuhan dalam penerapan cuci tangan perawat 
yang patuh sebanyak 6 orang, sedangkan yang tidak patuh sebanyak 10 orang.

Dari hasil uji statistik dengan menggunakan chi-square didapatkan hasil bahwa tidak ada hubungan yang bermakna antara kuisioner penerapan social distancing dengan ceklist obersvasi terdapat pada profesi tenaga administrasi sebesar $(1,000)<0,05$. Sedangkan pada profesi perawat sebesar $(0,518)$ $>0,05$. Pada profesi tenaga dokter mengasilkan pvalue sebesar $(1,000)>0,05$, dan pada profesi tenaga administrasi menghasilkan pvalue sebesar $(0,400)>0,05$. Pada tenaga kessehatan yang memasuki wilayah kerja GBPT dapat disimpulkan bahwa tidak adanya hubungan yang bermakna antara kuisoner dengan ceklist observasi tentang penerapan social distancing.

Adanya kebiajakan mengenai social distancing sangat penting dan efektif dalam mengurangi penyebaran pnyebaran COVID-19, dapat membantu mencegah meluapnya system kesehatan atau tenaga kesehatan yang kewalahan, dan juga dapat mengurangi kematian yang disebabkan oleh virus COVID-19 (10). Masyarakat dapat membantu mengurangi penyebaran virus COVID-19 dengan menrapka langkah-langkah yang benar dalam menerapkan social distancing. Setelah dikeluarkannya kebijakan mengenai social distancing di masyarakat angka penurunan kasus yang terkonfirmasi positif COVID-19 menurun dibandingkan dengan setelah dikeluarkannya kebijakan lockdown seperti membatasi pertemuan dan penutupan sekolah. Akan tetapi masih banyak masyarakat yang masih bertemu. ${ }^{10}$

Penerapan social distancing dalam upaya pencegahan penyebaran COVID-19 tertuang dalam kebijakan Peraturan Gubernur Jawa Timur tahun 2020 tentang Pedoman Pembatasan Sosial Berskala Besar dalam Penanganan Corona Virus Disease 2019 (COVID-19) di Wilayah Surabaya Raya. Kebijakan tersebut berlaku disegala sekto formal maupun informal. Rumah sakit salah satu sector pelayanan utama yang wajib menerapkan kebijakan social distancing dalam melaksanakan pelayanan dan berinteraksi atau berkomunikasi dengan orang lain.

Berdasarkan hasil penelitian kepatuhan dan persepsi responden diperoleh pvalue sebesar 0,793 pada seluruh responden dan oleh karena nilai pvalue $(0,793>0,05)$, sehingga berarti tidak adanya hubungan bermakna antara persepsi pentingnya penerapan social distancing dengan kepatuhan penerapan social distancing pada tenaga kesehatan yang berada di wilayah kerja Instalasi GBPT RSUD Dr. Soetomo Surabaya. Meskipun tidak menunjukkan ada hubungan, akan tetapi hasil ceklist obeservasi menunjukkan bahwam masih tingginya angka ketidak patuhan tenaga kesehatan yang berada di wilayah GBPT RSUD Dr. Soetomo dalam menerapkan social distancing pada saat berkomunikasi ataupun berinteraksi dengan orang di sekitarnya.

\section{Kesimpulan}

Petugas kesehatan yang berada atau mengunjungi GBPT terdiri dari beberapa profesi, diantaranya dokter, perawat, petugas administrasi, dan transporter. Persepsi tentang pentingnya penggunaan masker, penerapan cuci tangan, dan penerapan social distancing pada petugas yang berada di GBPT RSUD Dr. Soetomo secara umum termasuk ke dalam kategori baik. Sedangkan dalam tingkat kepatuhan dalam penggunaan masker, penerapan cuci tangan, maupun penerapan social distancing pada petugas kesehatan yang berada di GBPT RSUD Dr. Soetomo masih perlu ditingkatkan terutama pada tenaga administrasi.

Dari hasil penelitian ini dapat disimpulkan bahwa adanya hubungan yang bermakna antara persepsi petugas kesehatan dengan kepatuhan terhadap himbauan pemakaian masker di area GBPT RSUD Dr. Soetomo dalam upaya pencegahan penyebaran wabah COVID-19 pada tenaga kesehatan terutama yang berprofesi sebagai perawat. Sedangkan pada persepsi penerapan cuci tangan dan penerapan social distancing dengan kepatuhan penerapan cuci tangan dan penerapan social distancing tidak 
memiliki hubungan yang bermakna diantara kedua pada semua profesi tenaga kesehatan.

\section{Ucapan Terima Kasih}

Terima kasih yang sebesar-besarnya kepada pegawai RSUD dr. Soetomo yang telah berpartisipasi pada penelitian ini sehingga dapat terselesaikan dengan baik.

\section{Referensi}

1. World Health Organization. Advice on the use of masks in the context of COVID-19: interim guidance-2. Geneva: WHO; 2020.

2. Pemerintah Provinsi Jawa Timur. JATIM Tanggap COVID-19 [Internet]. Republik Indonesia. 2020 [cited 2020 July 21]. Available from: http://infocovid19.jatimprov.go.id/

3. Pedoman Pembatasan Sosial Berskala Besardalam Penanganan Coronavirus Disease 2019 (COVID-19) di Provinsi Jawa Timur. Peraturan Gubernur Jawa Timur Nomor 18 Tahun 2020 [Internet]. 2020 Apr [cited 2020 Jul 21]. Available from: https://www.suarasurabaya.net/wpcontent/uploads/2020/04/Pergub-No.-18Tahun-2020-tentang-PSBB.pdf.

4. Zahara RA, Effendi SU, Khairani N. Kepatuhan Menggunakan Alat Pelindung Diri (APD) Ditinjau dari Pengetahuan dan Perilaku pada Petugas Instalasi Pemeliharaan Sarana Dan Prasarana Rumah Sakit (IPSRS). J Aisyah J Ilmu Kesehat. [Internet]. 2017 Dec [cited 2020 Jul 21];2(2):153-8. Available from: https://doi.org/10.30604/jika.v2i2.60.

5. Putri KDS, Denny Y. Analisis Faktor Yang Berhubungan Dengan Kepatuhan Menggunakan Alat Pelindung Diri. The Indonesian Journal of Occupational Safety , Health and Environment [Internet]. 2014 [cited 2020 Jul 21];1(1):24-36. Available from:

http://www.journal.unair.ac.id/downloadfullpapers-kklk1d0764ead72full.pdf

6. Apriluana G, Khairiyati L, Setyaningrum R.
Hubungan Antara Usia, Jenis Kelamin, Lama Kerja, Pengetahuan, Sikap Dan Ketersediaan Alat Pelindung Diri (APD) Dengan Perilaku Penggunaan Apd Pada Tenaga Kesehatan. Jurnal Publikasi Kesehatan Masyarakat Indonesia [Internet]. 2016 [cited 2020 July 21];3(3):82-7. Available from: https://ppjp.ulm.ac.id/journal/index.php/JPK MI/article/view/2754/2400.

7. Rikayanti KH, Arta SK. Hubungan Tingkat Pengetahuan Dengan Perilaku Mencuci Tangan Petugas Kesehatan Di Rumah Sakit Umum Daerah Badung Tahun 2013. Community Health [Internet]. 2014 Jan [cited 2020 July 21];2(1):21-31. Available from:

https://ojs.unud.ac.id/index.php/jch/article/vi ew/7693/5783.

8. Fajriyah NN. Pengetahuan Mencuci Tangan Penunggu Pasien Menggunakan Lotion Antiseptic. In Prosiding Seminar Nasional dan Internasional [Internet]. 2015 [cited 2020 Jul 21]. Available from: https://jurnal.unimus.ac.id/index.php/psn120 12010/article/view/1636.

9. Arsabani FN, Hadianti NPN. Hubungan Ketersediaan Sumber Daya, Kepemimpinan, Lama Kerja, dan Persepsi dengan Kepatuhan Mencuci Tangan Lima Momen di Rumah Sakit Islam Surabaya. J Keperawatan Muhammadiyah [Internet]. 2019 Jun [cited 2020 Jul 21];4(1):41-47. Available from: https://doi.org/10.30651/jkm.v4i1.2011.

10. Dreher N, Spiera Z, McAuley FM, Kuohn L, Durbin JR, Marayati NF, et al. Impact of policy interventions and social distancing on SARS-CoV-2 transmission in the United States. medRxiv [Internet]. 2020 May [cited 2020 Jul 21];2020.05.01.20088179. Available from: https://doi.org/10.1101/2020.05.01.2008817 9. 